\title{
EFFECT OF META-TOPOLIN ON IN VITRO PROPAGATION OF PELARGONIUM $\times$ HORTORUM AND PELARGONIUM $\times$ HEDERAEFOLIUM CULTIVARS
}

\author{
AGNIESZKA WOJTANIA \\ Szczepan Pieniążek Research Institute of Pomology and Floriculture \\ Pomologiczna 18, 96-100 Skierniewice, Poland \\ e-mail: agnieszka.wojtania@insad.pl
}

(Received: November 30, 2009. Accepted: May 2, 2010)

\begin{abstract}
The aim of this study was to develop an efficient in vitro propagation method of Pelargonium plant (seven cultivars) using axillary buds and shoot tips as explants. The influence of the time period in which the explants were collected and the influence of the growth regulators (BAP, meta-topolin, IBA) were studied.

The explants taken in April had a higher regeneration ability than those isolated in July and September. The most efficient regeneration and axillary multiplication were achieved on the medium supplemented with meta-topolin. The application of BAP caused a lower regeneration potency of explants and resulted in a decrease of shoot quality with every subculture. Four of the six cultivars showed growth inhibition after three months of growth on BAP-medium. The highest multiplication rate (2.7-4.7 depending on genotype) and the high quality of shoots were noted on the medium supplemented with $m \mathrm{~T}\left(0.5-1.0 \mathrm{mg} \mathrm{l}^{-1}\right)$. It is also very important to note that $m \mathrm{~T}$ had stimulating effect on organogenesis in $P . \times$ hederaefolium and $P . \times$ hortorum cultivars over the long term. Moreover, meta-topolin had no after-effect on the growth and inhibition of rooting. Only one cultivar ('Sofie Cascade') rooted better on control medium without auxin. In case of the other cultivars, IBA added in concentrations of 0.01-0.1 $\mathrm{mg} \mathrm{l}^{-1}$ had a stimulating effect on root production. The higher level of auxin inhibited root formation, stimulated senescence of shoots and had a negative after-effect on acclimatization in greenhouse conditions.
\end{abstract}

KEY WORDS: micropropagation, cytokinins, shoot and root formation, Pelargonium.

\section{INTRODUCTION}

The basic factor for a profitable mass production of $\mathrm{Pe}$ largonium $\times$ hortorum and Pelargonium $\times$ hederaefolium cultivars is a healthy starting material. Micropropagation based on axillary shoot growth is a good system for maintaining an in vitro stock of pathogen-free mother plants (Reuther 1988). The regeneration of Pelargonium cultures from axillary buds as well shoot tips and meristem explants has been reported by many researches (Hamdorf 1976; Theiler 1977; Reuther 1983, 1988; Cassells and Minas 1983; Cassells and Carney 1987; Horn 1988; Corneanu and Corneanu 1991; Desilets et al. 1993). However, very often regeneration was obtained indirectly by callus, which is a very easy form, especially in Pelargonium $\times$ hederaefolium cultivars. The main problem in the propagation of Pelargonium in vitro is fast senescence and loss of regene-

\section{Abbreviations}

BAP - 6-benzylaminopurine; IBA - 3-indolebutyric acid; $m$ T (meta-topolin) - 6-(3-hydroxybenzylamino)purine; MS - Murashige and Skoog medium; $2 \mathrm{iP}$ - isopentyladenine ration ability in the initiated shoots of various cultivars (Reuther 1988; Paludan 1991; Desilets et al. 1993; Mithila et al. 2001). It is a serious limiting factor in maintaining stock cultures over the long term.

The results of an earlier study showed that natural cytokinin - meta-topolin ( $m$ T) (Strnad et al. 1992; Strnad 1997), had a positive influence on shoot multiplication of $P . \times$ hederaefolium 'Bonete' and $P . \times$ hortorum 'Bergpalais' (Wojtania and Gabryszewska 2001). The objective of this study was to compare the effect of $m \mathrm{~T}$ and BAP (the most widely recommended cytokinins in the propagation of this plant) on initiation of the culture, as well as longterm multiplication and rooting of seven cultivars of Pelargonium in vitro.

\section{MATERIAL AND METHODS}

The experiments were performed with seven Pelargonium cultivars: $(P . \times$ hederaefolium 'Luna', 'Sofie Cascade', 'Beach' and $P . \times$ hortorum 'White Rocky Mountain', 'Jazz Rocky Mountain', 'Grand Prix', 'Bergpalais'). 
In vitro cultures of shoots were established, multiplicated and rooted on MS media (Murashige and Skoog 1962) supplemented with $30 \mathrm{~g} \mathrm{l}^{-1}$ sucrose, $0.1 \mathrm{~g} \mathrm{l}^{-1}$ myo-inositol and solidified with LAB-AGAR $\left(5.5 \mathrm{~g}^{-1}\right)$. The $\mathrm{pH}$ of the medium was adjused to 5.6 before autoclaving. The shoots were subcultured at 3-4 weeks' intervals into fresh medium in an Erlenmeyer flask and kept at the temperature of $20^{\circ} \mathrm{C}$, under a $16 \mathrm{~h}$ photoperiod provided by cool-white fluorescent lamps at $40 \mu \mathrm{mol} \mathrm{m} \mathrm{m}^{-2} \mathrm{~s}^{-1}$ (Philips TLD 36W/95).

\section{Culture establishment}

Shoot-tips and axillary buds collected from Pelargonium plants grown in the greenhouse were used for culture initiation. The explants were excised in April, July and September and after sterilization (3\% Chloramine $\mathrm{T}$ and $0.1 \%$ $\mathrm{HgCl}_{2}$ ) were placed in the MS medium containing the cytokinin: $\operatorname{BAP}\left(0.1 \mathrm{mg} \mathrm{l}^{-1}\right)$ or meta-topolin $\left(0.2 \mathrm{mg} \mathrm{l}^{-1}\right)$ and IBA at concentration of $0.02 \mathrm{mg} \mathrm{l}^{-1}$ (Wojtania and Gabryszewska 2004). One individual explant was placed in each $50 \mathrm{ml}$ Erlenmeyer flask. At least 60 replications were used. The number of buds which developed into shoots was estimated after four weeks.

\section{Shoot multiplication}

The initiated Pelargonium shoots were then transferred to the medium supplemented with $\mathrm{BAP}\left(0.5 \mathrm{mg} \mathrm{l}^{-1}\right)$ or $m e$ ta-topolin $\left(0.5 ; 1.0 \mathrm{mg} \mathrm{l}^{-1}\right)$. Application of cytokinins in different concentrations resulted from their different activity noted for other genotypes (Werbrouck et al. 1996;
Podwyszyńska et al. 2000) and Pelargonium cultivars (Wojtania and Gabryszewska 2001).

The shoots were subcultured every four weeks. The number of shoots was determined after 4, 8, 16, 20 and 24 weeks of the culture. The number of leaves and length of shoots $(\mathrm{mm})$ were also measured of the explants grown on media without growth regulators (control) and supplemented with $m \mathrm{~T}$. The experiment was repeated three times. One experimental treatment was represented by 30 explants $(6 \times 5$ explants per Erlenmeyer flask). Data were subjected to analysis of variance and the means were compared by Duncan's test at significance level $P=0.05$. Analysis of variance and differences between mean values were determined separately for each cultivar.

\section{Rooting and acclimatization}

The after-effect of the $m \mathrm{~T}$ on the rooting of seven Pelargonium cultivars shoots was evaluated. The single shoots $(>10 \mathrm{~mm})$ were rooted on MS medium without growth regulators or supplemented with IBA at different concentrations $\left(0.01 ; 0.1 ; 0.2 ; 0.5 \mathrm{mg} \mathrm{l}^{-1}\right)$. The number of rooted shoots was determined after three weeks. The experiment was repeated twice. One experimental treatment was represented by 30 explants $(6 \times 5$ explants per Erlenmeyer flask). The rooted microcuttings were planted in a growing substrate composed of peat and perlite (1:4), supplemented with complete fertilizer (Azofoska) at $0.5 \mathrm{~g} \mathrm{l}^{-1}$ and in relatively high humidity.
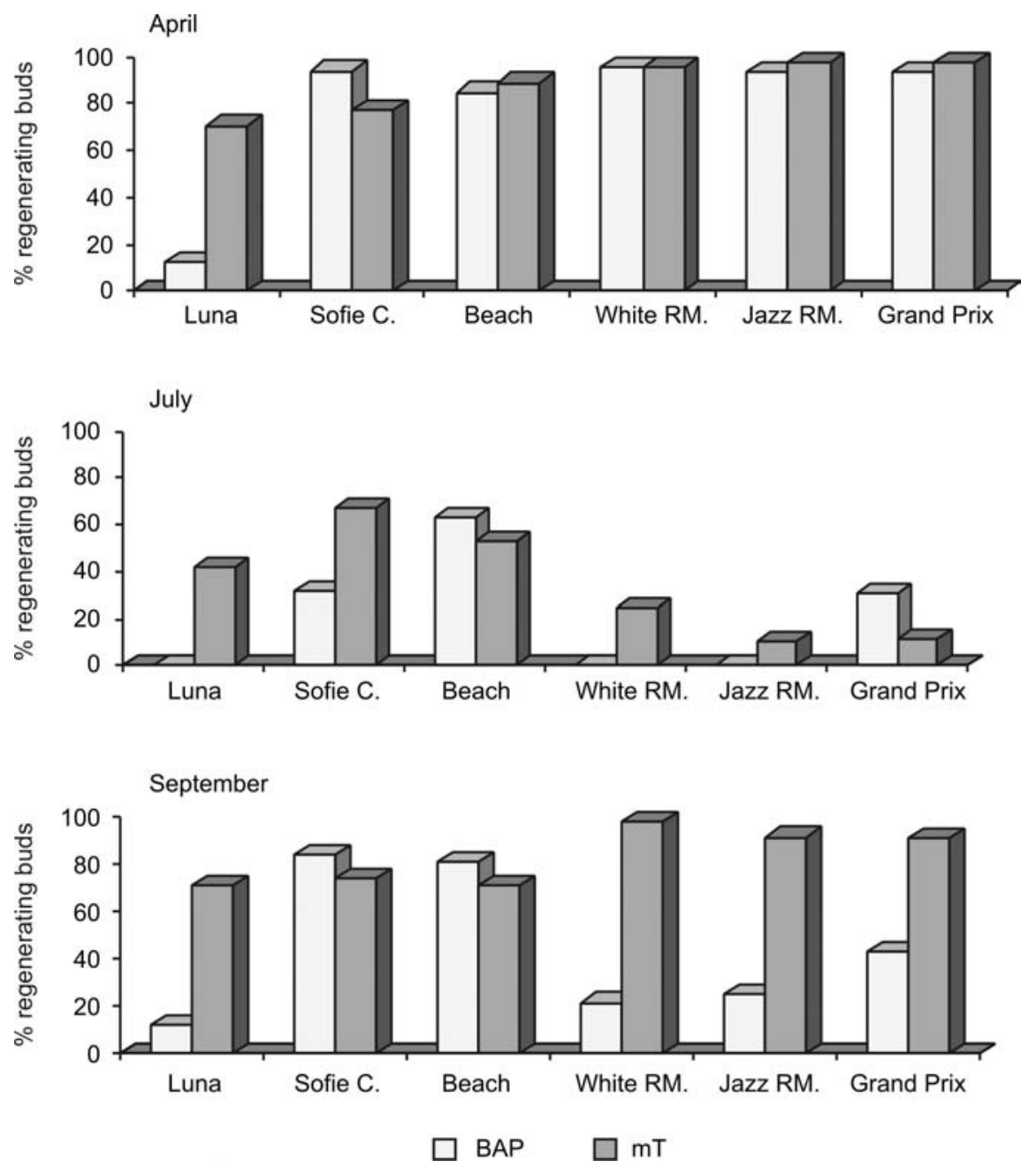

Fig. 1. The effect of type of cytokinin and the season in which explants were collected on the number $(\%)$ of buds which developed into single shoots of $P . \times$ hederaefolium ('Luna', 'Sofie-Cascade', 'Beach') and $P . \times$ hortorum ('White Rocky Mountain', 'Jazz Rocky Mountain','Grand Prix'). BAP (0.1 $\left.\mathrm{mg} \mathrm{l}^{-1}\right)$ or $m \mathrm{~T}\left(0.2 \mathrm{mg} \mathrm{l}^{-1}\right)$ were added together with IBA $\left(0.02 \mathrm{mg} \mathrm{l}^{-1}\right)$. 


\section{RESULTS AND DISCUSSION}

\section{Culture establishment}

On MS medium supplemented with meta-topolin $(m \mathrm{~T})$ $\left(0.2 \mathrm{mg} \mathrm{l}^{-1}\right)$, as well as BAP $\left(0.1 \mathrm{mg} \mathrm{l}^{-1}\right)$ added together with IBA $\left(0.02 \mathrm{mg} \mathrm{l}^{-1}\right)$, shoot tips and axillary buds of all Pelargonium cultivars developed into a single shoot. The efficiency of this process depended on type of the cytokinin, the term of explants collecting and genotype (Fig. 1). According to genotype the shoots developed in 2-4 weeks. The best initiation of Pelargonium cultures was observed in April (Fig. 1), when mother plant showed intensive vegetative growth. Similar results were obtained by Corneanu and Corneanu (1991) in P. $\times$ hortorum and P. $\times$ domesticum. In the present study there were no significant differences between cytokinin treatments in growth and development of buds in most Pelargonium cultivars (except for 'Luna') when explants were collected in the spring. Recorded were $85-97,8 \%$ of regenerating explants in the presence of BAP and $77,5-100 \%$ on the $m$ T-medium (Fig. 1). In 'Luna' (recalcitrant in vitro), the use of $m \mathrm{~T}$ resulted in a six-fold increase in number of buds which developed into shoots as compared with the BAP treatment. Moreover, application of $m \mathrm{~T}$ enhanced, approximate three-fold the regeneration frequency of some $P . \times$ hortorum cultivars in July and two-fold, when explants were excised in September (Fig. 1). A lower regeneration ability of shoot buds in July and September could be correlated with changes in synthesis, transport, interaction and balance between endogenous

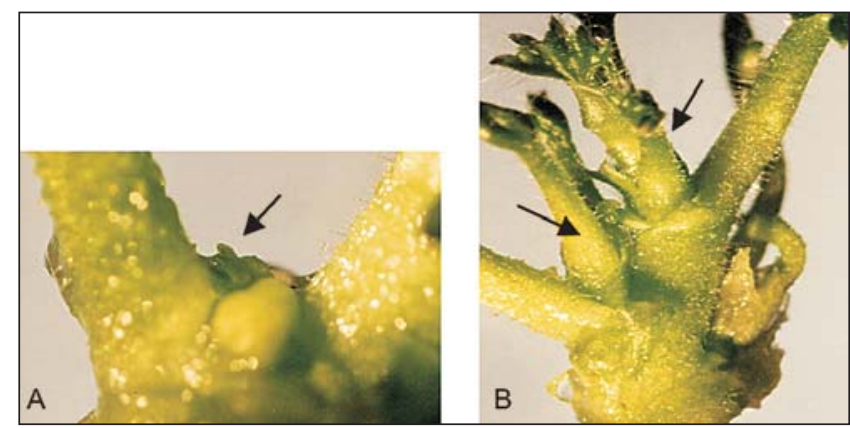

Fig. 2. The activity of axillary buds in $P . \times$ hederaefolium 'Beach' after three weeks of growth on the medium containing: A - BAP $\left(0.5 \mathrm{mg} \mathrm{l}^{-1}\right)$, $\left.\mathrm{B}-m \mathrm{~T} .1 .0 \mathrm{mg}^{-1}\right)$. Developing buds were marked with an arrow.

phytohormones, as well as with changes in sensitivity of the cell to the exogenous cytokinin (Gaspar et al. 2003; del Pozo et al. 2005). In the case of $P . \times$ hederaefolium 'Luna', which showed only a little or no organogenic potency in the presence of BAP (depending on the term of explants' collecting), $m \mathrm{~T}$ was able to stimulate the growth of shoots. In previous reports (Theiler 1977; Reuther 1983), using such cytokinins as BAP, $2 \mathrm{iP}$ and kinetin indicated that the recalcitrant genotype of Pelargonium developed only non organogenic callus and finally died. The present study showed that among the tested cytokinins only $m \mathrm{~T}$ influenced the high quality of initiated shoots (well-developed, without vitrification). This is very important for further growth and development of Pelargonium in vitro.
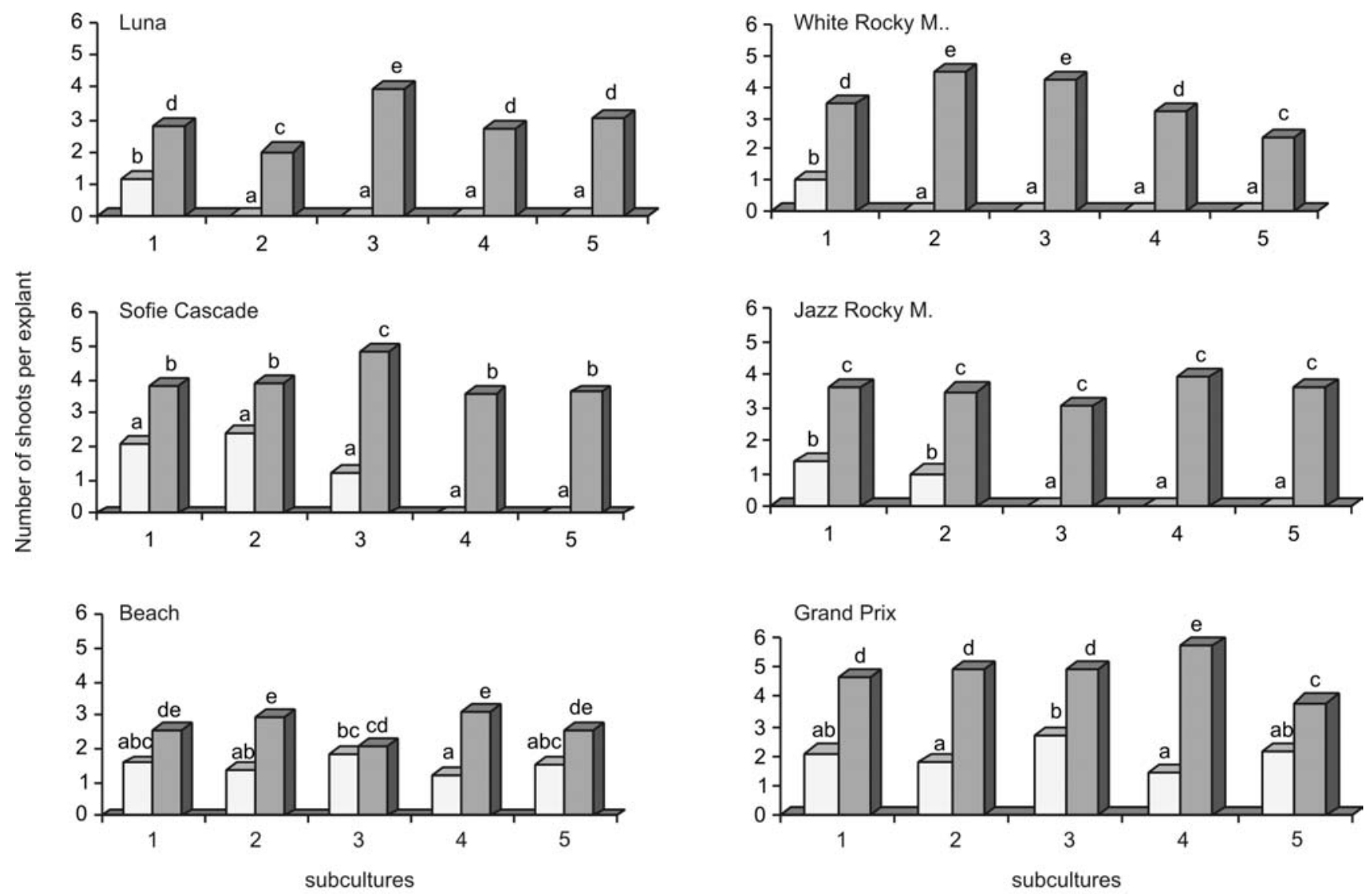

BAP

$m T$

Fig. 3. The survival and multiplication rate of the different cultivars of $P . \times$ hederaefolium and $P . \times$ hortorum through five subcultures. Means of each cultivar assigned by the same letter do not differ significantly $(\mathrm{P}=0.05)$ with Duncan's test. 

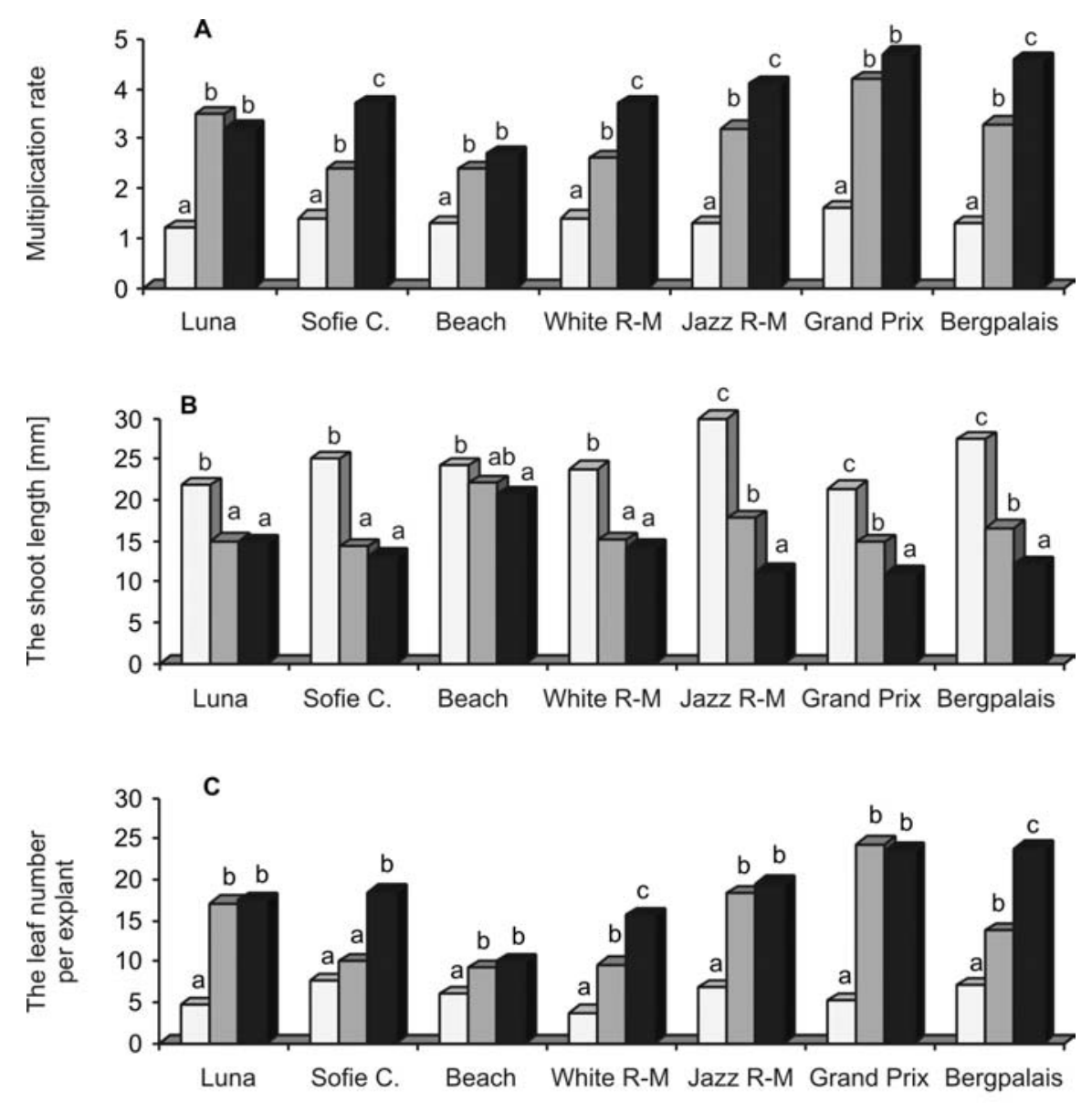

Fig. 4. The effect of different concentration of meta-topolin on the multiplication rate (A), the length of shoots (B) and the number of leaves (C) in 3 genotypes of $P . \times$ hederaefolium ('Luna', 'Sofie-Cascade', 'Beach') and 4 genotypes of $P . \times$ hortorum $\mathrm{P}$ ('White Rocky Mountain', 'Jazz Rocky Mountain', 'Grand Prix', 'Bergpalais'). Means of each cultivar assigned by the same letter do not differ significantly $(\mathrm{P}=0.05)$ with Duncan's test.

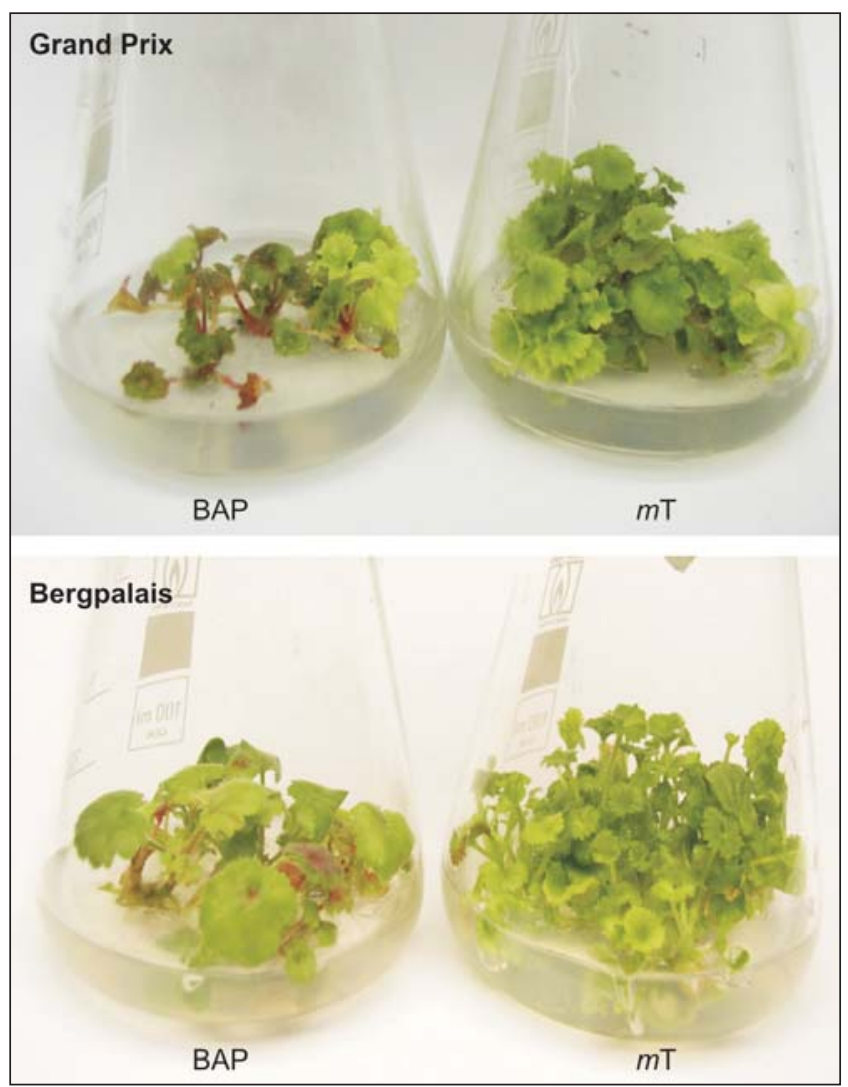

Fig. 5. The shoots of two Pelargonium cultivars after three weeks of growth on MS medium containing BAP or $m \mathrm{~T}$.

\section{Shoot multiplication}

The established, single shoots of different Pelargonium cultivars were transferred to a MS medium containing BAP $\left(0.5 \mathrm{mg} \mathrm{l}^{-1}\right)$ or $m \mathrm{~T}\left(0.5 ; 1.0 \mathrm{mg} \mathrm{l}^{-1}\right)$ for shoot multiplication. There were clear differences between the cytokinin treatments. Adventitious multiplication was found in the presence of BAP. The axillary buds did not develop into shoots (Fig. 2). Very often, the adventitious shoots were vitrified and deformed, the callus (intensively formed at the base of the shoots) had a tendency to browning and this kind of culture finally died. In 'Luna' BAP affected senescence of cultures after the first subculture, for 'Jazz Rocky Mountain' after the second subculture and for 'Sofie Cascade' after the third subculture (Fig. 3). In the case of genotypes with red flowers ('Beach' and 'Grand Prix'), BAP stimulated adventitious shoot formation over the long term, but the multiplication rate was lower than those obtained on $m \mathrm{~T}$ medium; the average 1,0-1,9 shoots/explant (Fig. 3).

The present study showed that in contrast to BAP, in the presence of $m \mathrm{~T}$ it was possible to obtain axillary multiplication of all Pelargonium cultivars (Fig. 2 and 3), even for the next few years (unpublished data). Moreover, it was observed that the effectiveness of shoot formation depended on the cultivar and varied between subcultures (Fig. 4). The highest multiplication rate (average 4.8 shoots/eksplant) was obtained in $P . \times$ hortorum 'Grand Prix' by using $1.0 \mathrm{mg}^{-1} \mathrm{mT}$ and the lowest $(2.7$ shoots/explants) in $P . \times$ hederaefolium 'Beach' (Fig. 4). A similar concentration of $m \mathrm{~T}$ was optimal for effective multiplication of shoots in 
other plants, such as Musa (Escalona et al. 2003), Aloe polyphylla (Bairu et al. 2007), Magnolia $\times$ soulangeana, Coccoloba uvifera i Actinidia chinensis (Podwyszyńska et al. 2000). As Werbrouck et al. (1996) and Podwyszyńska et al. (2000) reported, some plants needed a two-fold higher concentration of $m \mathrm{~T}$ than BAP to obtain a similar number of shoots. In Beta vulgaris cultures, $m \mathrm{~T}$ was more active than zeatin (Kubaláková and Strnad 1992). The present study showed also that an increased concentration of $m \mathrm{~T}$ (0.5-1.0 $\left.\mathrm{mg}^{-1}\right)$ enhanced the number of leaves per explants and decreased the length of shoots (Fig. 4). For the same genotype ('Luna', 'Grand Prix') the first symptoms of vitrification were also observed. A further increase in the $m \mathrm{~T}$ level up to $1.5 \mathrm{mg}^{-1}$ stimulated shoot formation, but simultaneously a rapid decrease of shoot quality was noted (vitrification, deformation and occasionally fasciation of shoots) (data not presented).

Similar to Beta vulgaris, Musa AAB, Malus $\times$ domestica and Aloe polyphylla (Kubalákowa and Strnad 1992; Escalona et al. 2003; Dobránszki et al. 2002; Bairu et al. 2007) in Pelargonium, $m \mathrm{~T}$ resulted in higher shoot quality than the other cytokinin. As showed in this study, on $m \mathrm{~T}-\mathrm{me}-$ dium all Pelargonium cultivars produced juvenile, well developed shoots, with high chlorophyll content (Fig. 5). Moreover, $m \mathrm{~T}$ was able to prevent the senescence of Pelargonium shoots. The inhibition of senescence by $m \mathrm{~T}$ was previously observed in the wheat chlorophyll retention bioassay (Holub et al. 1998; Palavan-Ünsal et al. 2004), radish cotyledons (Cað and Palavan-Ünsal 2003) and potato 'Kennebec' cultures as well Zantedeschia aethiopica fruit (Baroja-Fernandez et al. 2002). It is known that formation of not organonogenic callus and fast senescence of cultures were the major factors, which limited obtaining the longterm multiplication of Pelargonium shoots in vitro (Desilets et al. 1993; Mithila et al. 2001). It is also very important that $m \mathrm{~T}$ had a stimulating effect on shoot formation for $P . \times$ hederaefolium, as well as $P . \times$ hortorum cultivars. They often exhibited variety-specific differences in regeneration potential and required specific growth regulators (Hamdorf 1976; Theiler 1977; Reuther 1983).

Werbrouck et al. (1996) demonstrated that the difference between BAP and $m \mathrm{~T}$ on cultures of Spathiphyllum flori-

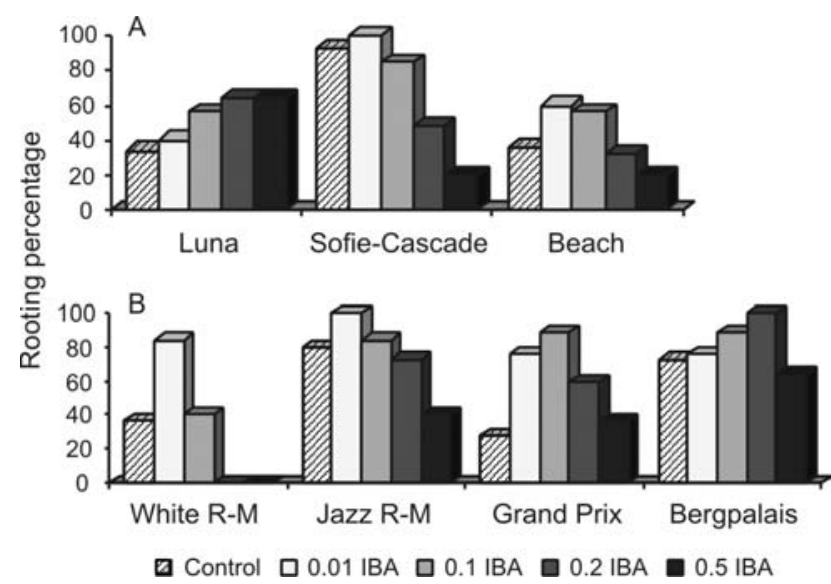

Fig. 6. The in vitro rooting of Pelargonium on control medium (without growth regulators) or after treatment with different IBA concentrations. A $-P . \times$ hederaefolium cultivars; B $-P . \times$ hortorum cultivars. Means of each cultivar assigned by the same letter do not differ significantly $(\mathrm{P}=0.05)$ with Duncan's test.

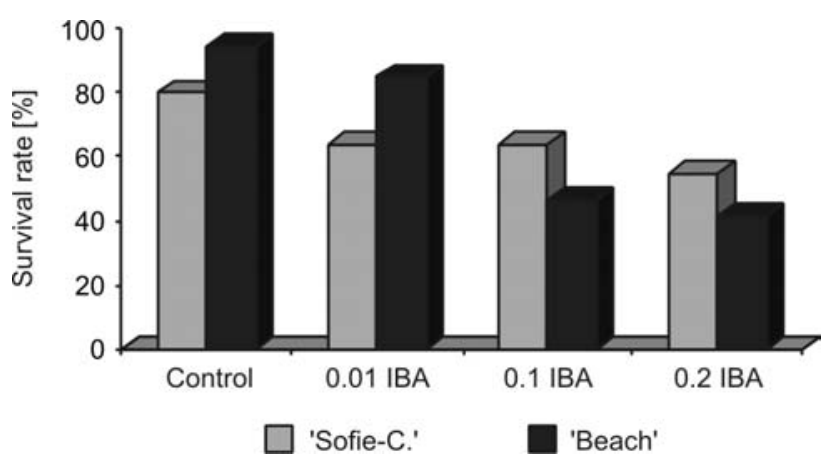

Fig. 7. The after-effect of IBA on survival rate of Pelargonium microcutting in greenhouse conditions.

bundum resulted from slight structural differences. It is known that unlike BAP, $m \mathrm{~T}$ is translocated faster in plant tissue, which prevents its localized accumulation (Kaminek et al. 1987). Current knowledge suggests that responses to cytokinin are mediated by a family of receptors, which regulate a signal-transduction pathway (Heyl and Schmülling 2003). As reported by Mok et al. (2005), BAP and $m$ T have a different affinity in receptor recognition. The authors found that $m \mathrm{~T}$ like trans-zeatin interacts with the Arabidopsis AHK4 receptor while BAP and TDZ with the maize ZmHK1 receptor.

\section{Rooting of shoots}

It is known that root formation in Pelargonium plants in vitro depends on the quality of the shoots. As reported by Reuther (1983) and Corneanu and Corneanu (1991) only well-developed shoots, longer than $1.0 \mathrm{~cm}$, were easy to root. The present study showed that the shoots of all the Pelargonium cultivars derived from the $m \mathrm{~T}$-medium, produced roots on the control medium (without growth regulators) as well in the presence of IBA (Fig. 6). The ability to root depended on the genotype. The lowest rooting percentage $(56 \%)$ was noted for $P . \times$ hederaefolium 'Beach' (Fig. 6). 'Sofie Cascade' rooted better on the control medium than on those supplemented with auxin. In other cultivars, IBA stimulated the root formation, but only at low concentrations (0.01-0.1 $\left.\mathrm{mg} \mathrm{l}^{-1}\right)$. A high level of auxin, inhibited root formation, stimulated senescence of shoots and had a negative after-effect on acclimatisation in greenhouse conditions (Fig. 7).

\section{CONCLUSIONS}

The results of the present study indicated that $m \mathrm{~T}$ plays an important role in morphogenesis of Pelargonium in vitro. This cytokinin has a positive influence both on growth and development of shoots and their quality. The use of $m \mathrm{~T}$ makes possible the initiation of cultures of recalcitrant cultivars in the wider range of deadlines as compared with BAP, axillary multiplication of over the long term and further rooting of shoots. Its positive influence on $P . \times$ hederaefolium as well as $P . \times$ hortorum is also very important. The above results suggest that $m \mathrm{~T}$ can be very useful in micropropagation of various Pelargonium cultivars. 


\section{ACKNOWLEDGMENTS}

The authoress sincerely thanks Dr Eleonora Gabryszewska for her helpful advice, and Lidia Tułacz for her technical assistance.

This research was partially supported by a grant from the Polish Ministry of Science and Higher Education No. 310004 32/0222.

\section{LITERATURE CITED}

BAIRU M.W., STIRK W.A., DOLEŽAL K., VAN STADEN J. 2007. Optimizing the micropropagation protocol for the endangered Aloe polyphylla: can meta-topolin and its derivatives serve as replacement for benzyladenine and zeatin? Plant Cell Tiss. Org. Cult. 90: 15-23.

BAROJA-FERNÁNDEZ E., AGUIRREOLEA J., MARTÍNKOVÁ H., HANUŠ J., STRNAD M. 2002. Aromatic cytokinins in micropropagated potato plants. Plant Physiol. Biochem. 40: 217-224.

CAG S., PALAVAN-ÜNSAL N. 2003. The effect of meta-topolin on protein profile in radish cotyledons. J. Cell Mol. Biol. 2: 31-34.

CASSELLS A.C., MINAS G. 1983. Plant and in vitro factor influencing the micropropagation of Pelargonium cultivars by bud-tip culture. Scientia Hortic. 21: 53-61.

CASSELLS A.C., CARNEY B.F. 1987. Adventitious regeneration in Pelargonium $\times$ domesticum Bailey. Acta Hortic. 212: 419-424.

CORNEANU M., CORNEANU G.C. 1991. The genotype, explant type and medium composition influence on in vitro multiplication in Pelargonium sp. Acta Hortic. 289: 101-102.

DEL POZO J.C., LOPEZ-MATAS M.A., RAMIREZ-PARRA E., GUTIERREZ C. 2005. Hormonal control of the plant cycle. Physiol. Plant. 123: 173-183.

DESILETS H., DESJARDINS Y., BELANGER R. 1993. Clonal propagation of Pelargonium $\times$ hortorum through tissue culture: Effects of salt dilution and growth regulator concentration. Can. J. Plant Sci. 73: 871-878.

DOBRÁNSZKI J., MAGYAR-TÁBORI K., JÁMBORBENCZÚR E., KISS E., LAZÁNYI J., BUBÁN T. 2002. Effect of conditioning apple shoots with meta-topolin on the morphogenic activity of in vitro leaves. Acta Agron. Hung. 50: 191-195.

ESCALONA M., CEJAS I., GONZÁLES-OLMEDO J., CAPOTE I., ROELS S., CAÑAL M.J., RODRÍGEZ R., SANDOVAL J., DEBERGH P. 2003. The effect of meta-topolin on plantain propagation using a temporary immersion bioreactor. InfoMusa 12:28-30.

GASPAR TH., KEVERS C., FAIVRE-RAMPANT., CREVECOEUR M., PENEL CL., GREPPIN H., DOMMES J. 2003. Changing concepts in plant hormone action. In Vitro Cell. Biol.-Plant 39: 85-106.

HAMDORF G. 1976. Propagation of Pelargonium varieties by stem-tip culture. Acta Hortic. 59 (Abstr.): www.actahort.org.

HEYL A., SCHMÜLLING T. 2003. Cytokinin signal perception and transduction. Current Opin. Plant Biol. 6: 480-488.
HOLUB J., HANUŠ J., HANKE D.E., STRNAD M. 1998. Biological activity of cytokinins derived from orto- and meta-hydroxybenzyladenine. Plant Growth Regul. 28: 109-115.

HORN W. 1988. Micropropagation of Pelargonium $\times$ domesticum (P.grandiflorum - hybrids). Acta Hortic. 226: 54-58.

KAMINEK M., VANĚK T., MOTYKA V. 1987. Cytokinin avtivities of $\mathrm{N}^{6}$-benzyladenosine derivatives hydroxylated on the side-chain phenyl ring. J. Plant Growth Regul. 6: 113-120.

KUBALÁKOVÁ M., STRNAD M. 1992. The effect of aromatic cytokinins on micropropagation and regeneration of sugarbeet in vitro. Biol. Plant. 34: 578-579.

MITHILA J., MURCH S.J., KRISHNARAJ S., SAXENA P.K. 2001. Recent advances in Pelargonium in vitro regeneration system. Plant Cell Tiss. Org. Cult. 67: 1-9.

MOK M.C., MARTIN R.C., DOBREV P.I., VANKOVÁ R., SHING HO P., YONEKURA-SAKAKIBARA K., SAKAKIBARA H., MOK D.W.S. 2005. Topolins and hydroxylated thidiazuron derivatives are substrates of cytokinin o-glucosyltransferase with position specificity related to receptor recognition. Plant Physiol. 137: 1057-1066.

MURASHIGE T., SKOOG F. 1962. A revised medium for rapid growth and bioassays with tobacco tissue cultures. Physiol. Plant. 15: 473-497.

PALAVAN-ÜNSAL N., ÇAG S., ÇETIN E. 2004. The role of meta-topolin in senescence of wheat leaf segments. J. Cell Mol. Biol. 3: 23-31.

PALUDAN N. 1991. Micropropagation, plantlet survival and variation of virus-infected and virus-free Pelargonium $\times$ hortorum and P. peltatum. In: Bridge, A report of Cost 87, (ed.) M. Appelgren, C.S. Hunter, N. Paludan, G. Reuther, R.T. TheilerHedtrich: 60-69.

PODWYSZYŃSKA M., WOJTANIA A., GABRYSZEWSKA E. 2000. $M$-topolina - mało znana cytokinina w mikrorozmnażaniu roślin. Zesz. Nauk. Inst. Sadow. i Kwiac. 7: 173-180. (in Polish)

REUTHER G. 1983. Propagation of disease-free pelargonium cultivars by tissue culture. Acta Hortic. 131: 311-319.

REUTHER G. 1988. Variability of Pelargonium peltatum cultivar in long-term in vitro culture of disease-free nucleus stock. Acta Hortic. 226: 647-654.

STRNAD M., PETERS W., BECK E., KAMINEK M. 1992. Immunodetection and identification of $\mathrm{N}^{6}-(o$-hydroxybenzulamino) purine as naturally occurring cytokinin in Populus $\times$ canadensis cv. Robusta leaves. Plant Physiol. 99: 74-80.

STRNAD M. 1997. The aromatic cytokinins. Physiol. Plant. 101: 674-688.

THEILER R. 1977. In vitro culture of shoot tips of Pelargonium species. Acta Hortic. 78: 403- 412.

WERBROUCK S.P.O., STRNAD M., VAN ONCKELEN H.A., DEBERGH P.C. 1996. Meta-topolin, an alternative to benzyladenine in tissue culture? Physiol. Plant. 98: 291-297.

WOJTANIA A., GABRYSZEWSKA E. 2001. Effect of cytokinins and amino acids on multiplication of Pelargonium cultivars. Acta Soc. Bot. Pol. 70: 203-207.

WOJTANIA A., GABRYSZEWSKA E. 2004. Wykorzystanie meta-topoliny w procesie wzrostu i rozwoju pędów Pelargonium $\times$ hortorum in vitro. Biotechnologia 2: 162-167. 